\title{
WIND / HYDROGEN HYBRID SYSTEMS: OPPORTUNITY FOR IRELAND'S WIND RESOURCE TO PROVIDE CONSISTENT SUSTAINABLE ENERGY SUPPLY
}

\author{
J. G. Carton*, A. G. Olabi, \\ Mechanical Engineering, Dublin City University, Dublin 9, Ireland \\ *James.carton3@mail.dcu.ie
}

\begin{abstract}
Ireland with its resource of wind has the potential to use this natural resource and sustain the country's power needs for the future. However, one of the biggest drawbacks to renewable energy generation, particularly wind generated electricity is that it is an intermittent and a variable source of power. Even at the "best" sites wind varies dramatically from hour to hour and minute to minute. This leads to two main problems:

1) When the wind drops below a lower limit or goes above a higher limit the turbine can shut down and electricity is not produced.

2) Energy is not stored when there is an excess of electricity generated on site.

Because of these problems wind power has a very low capacity credit and backup power is needed to handle the large fluctuation of production.

This paper introduces the energy system of Ireland and the targets that Irish operators are to achieve in the next decade. A review of energy storage options for Ireland is outlined including the use of hydrogen and fuel cell technology. It is concluded that a project similar to the Norwegian Utsira wind / hydrogen project could be piloted in Ireland and a site similar to Dundalk Institute of Technology could be used to demonstrate and test the system. Going forward to achieve high levels of renewable energy generation, similar distributed wind / hydrogen hybrid systems could reduce the need for curtailment of wind farms, save wasted energy, reduce backup power, reduce transmission losses, generate large revenue by selling power at peak times, ensure security of supply and reduce the need for costly interconnects to Europe.
\end{abstract}

KEYWORDS: PEM fuel cell, renewable energy storage, hydrogen, wind energy, Ireland.

\section{INTRODUCTION}

Rising fossil fuel prices, decreasing security of fuel supply and the desire to limit green house gas emissions are reasons the European Union (EU) have decided to stimulate an increase in Europe's use of renewable energy sources. By 2020 twenty percent of Europe's energy is to be derived from renewables [1].

Ireland sits on the periphery of Europe the calm Irish Sea to the east and the force of the Atlantic Ocean to the west. Weather systems travel across the expanse of the Atlantic heading east. One of the first obstacles to these weather systems for hundreds of kilometres is the island of Ireland. Strong south westerly winds penetrate the whole country the majority of the year. The potential for electricity generated by wind power is enormous for Ireland. In 2008 the government of Ireland set a target of $40 \%$ electricity consumption from renewable sources by 2020. In the 2001 European RES-E (renewable electricity) Directive, Ireland was set a target of moving from 3.6\% RES-E to $13.2 \%$ RES-E by 2010 . Ireland achieved $14.4 \%$ RES-E in 2009 and is on track to exceed the national target of $15 \%$ in 2010 . The significant 
growth in electricity from renewable sources in recent years is largely attributable to onshore wind $[2,3]$.

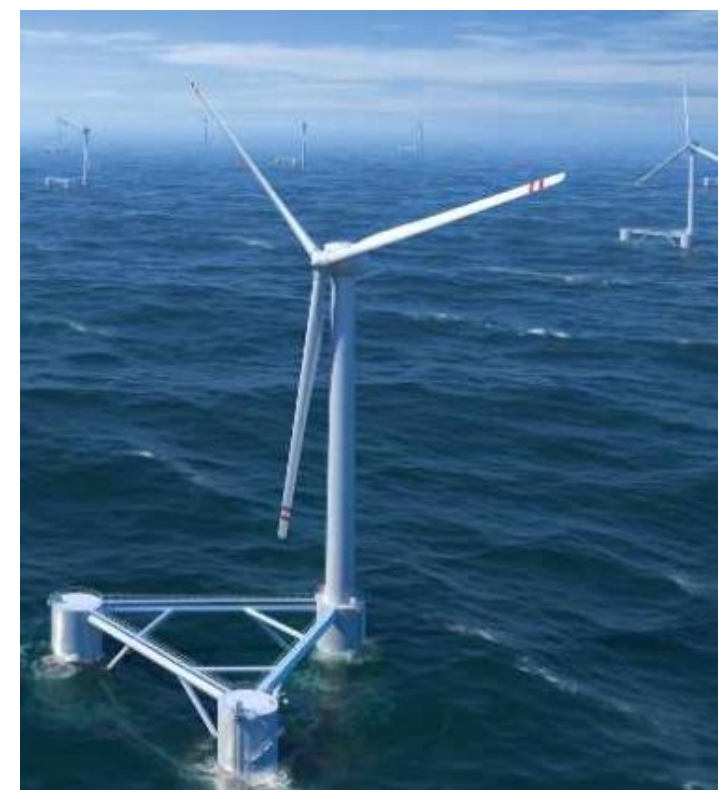

Figure 1 Oceanic wind power generation [43].

Wind power is a source of clean, non-polluting electricity, which is quite competitive, if installed at favourable wind sites, Figure 1, but as the penetration of renewable wind energy increases the Irish grid increasingly has to cope with the challenges posed by large amounts of intermittent power.

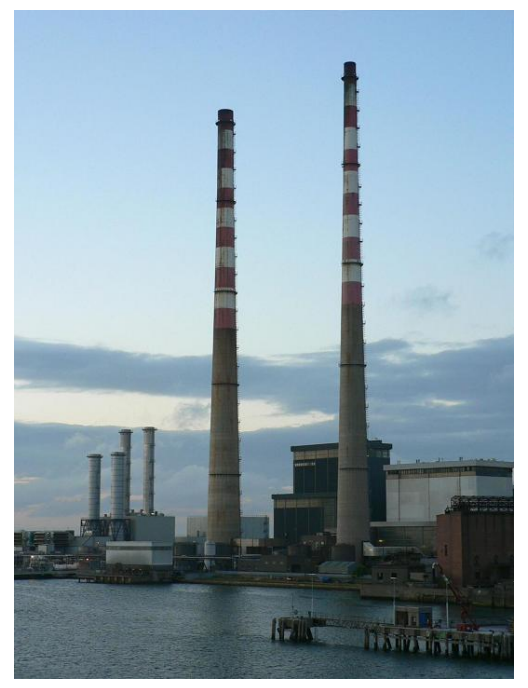

Figure 2 Poolbeg fossil fuel power station Ireland [4].

Wind power lacks controllability and unlike conventional power plants the output is not related to customer demand. If the wind increases strength there is a high risk that the wind turbines will suddenly have to cease operation while running at rated capacity, to avoid damage caused by over speed. During winter conditions, for example, a lot of excess electricity can be produced. If there are high winds, much fossil fuel-based or hydro-based reserves or other forms of backup power has to be available in case the critical wind speed is exceeded. Poolbeg power station, as shown in Figure 2 (in Dublin, Ireland), is a fossil fuelled power station that can be ramped up to high capacity when the grid electricity is not keeping 
with demand [4]. However ramping duty, the ability to pick up or reduce load on a power generating unit, is limited by the thermal and mechanical stresses imposed on the unit during the process of changing load levels. It is normal for manufacturers to specify a maximum permissible ramp-up and ramp down rate in terms of MW per minute. Ramp up rates in the range of 1 to $10 \mathrm{MW}$ per minute and ramp-down rates in the range from 1 to $15 \mathrm{MW}$ per minute are typical performance levels for thermal units. Turning on and off or ramping up and down power stations is quiet costly and results in spoiled fuel consumption. In any case the network operator has to pay for these services which can reduce the intrinsic economic value of electricity from renewables. Remembering that land based wind capital investment is about $€ 1200$ to $€ 1500$ per KW and this almost doubles for off shore installations. Reliable reserve power and/or storage capability is, therefore, necessary to ensure efficiency in supply $[5]$.

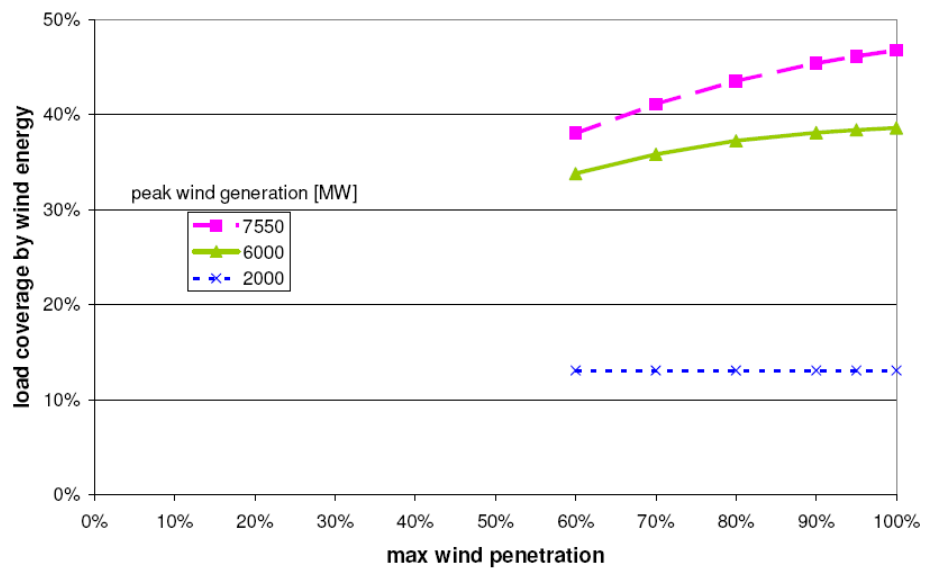

Figure 3 Estimated total wind energy share in annual load coverage due to curtailment for different maximum allowable instantaneous wind penetrations [6].

A study by Bomer et al. [6] for the Irish TSO, Eirgrid, has found that due to the technical characteristics of wind farms the increasing instantaneous penetration will alter the dynamics of the power system. It was reported that two key issues limit the acceptable level of instantaneous wind penetration; frequency stability after loss of generation \& frequency as well as transient stability after severe network faults. The study represents a comprehensive and detailed analysis of an all island power system for Ireland.

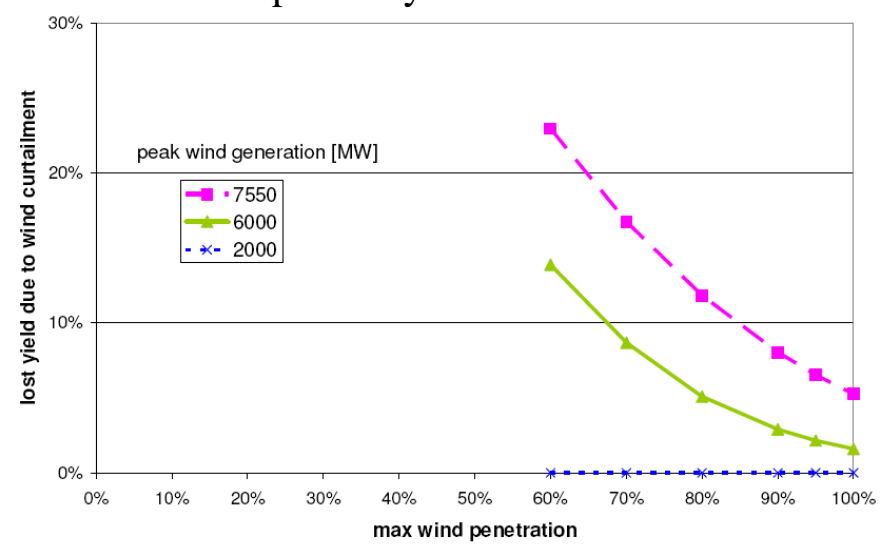

Figure 4 Estimated lost wind yield due to curtailment for different maximum allowable instantaneous wind penetrations [6].

The study suggests that if $7750 \mathrm{MW}$ of peak wind generation is installed by 2020 , instantaneous power from wind plus import may have to be limited to $60 \%$ and $80 \%$ of load 
plus export in 2020, but this will still allow achieving the 2020 renewable electricity targets in Ireland, Figure 3. However, 10\% of wind energy yield would be lost as a consequence of curtailment with $80 \%$ limit. The respective loss may increase to more than $20 \%$ of the potential generation applying a $60 \%$ limit, Figure 4.

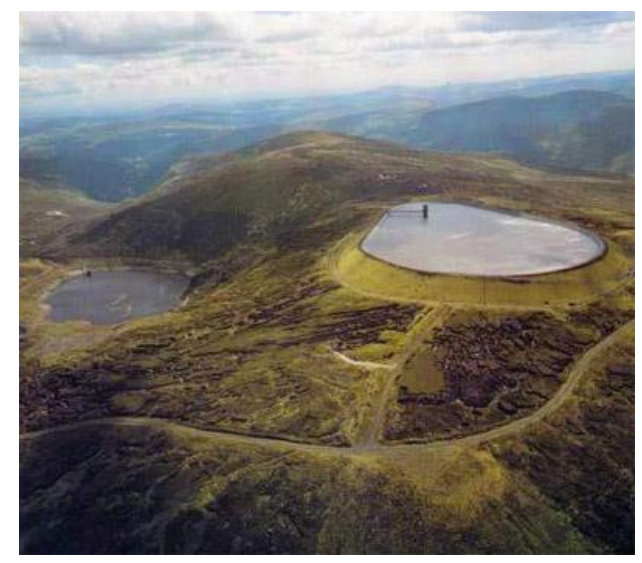

Figure 5 Turlough Hill pumped hydro power station Ireland [4].

\section{STORING ENERGY}

Wind generation is increasing substantially its share in the electricity generation portfolio in many countries. To become competitive in a liberalised market, wind energy reliability requirements should be guaranteed. Storage systems are being considered to avoid the impact on the electricity generation process of the lack of adequate winds. Energy storage is not a new concept. For example, hydro electric power stations store potential energy in their dammed lakes which is naturally filled by rivers. These stations usually operate at a medium power output, allowing the lake to fill to maximum for when extra capacity is needed by the grid. The applications for electricity storage technologies can be grouped as:

- Load management (load levelling, ramping and load following)

- Spinning reserve (fast response and conventional)

- System stability and voltage regulation

- Deferral of system and plant upgrading

- Renewable energy applications

- End user applications (UPS, peak shaving and emergency back-up).

In addition, with modern liberalised electricity markets electricity has become a commodity that can be bought and sold. Electricity operators can buy electricity at a low price, store it if possible and sell at a high price. The key characteristics of storage technologies that determine which applications they are most suited for are:

- Discharge duration

- Power rating

- Energy storage capacity

- Response time

- Costs in the context of benefits.

Many technologies exist that have been demonstrated or could potentially be used for energy storage. In relation to this paper pumped hydro and hydrogen storage are discussed. The reader is referred to [7-10] for other storage technologies.

\subsection{Pumped Hydro Energy Storage}


Utilities across the world have built a number of pumped-hydro facilities in the last few decades, resulting in a storage component of roughly 5\% the capacity of all the European countries, $3 \%$ in the US, and $10 \%$ in Japan. These pumped-hydro plants have been used for load levelling, frequency response, and voltage control [11].

The Turlough Hill scheme is the only one of its kind in Ireland. It is a pumped hydro power station consisting of an upper reservoir and lower lake, Figure 5. It was built in 1968 by the Irish electricity supply board (ESB). The station comprises four $73 \mathrm{MW}$ generators to give a total capacity of 292MW. Greater economy of operation is achieved because generating capacity from other stations can be used at periods of low demand to pump water from the lower lake to the upper reservoir where it is ready for use when demand increases. Greater flexibility is achieved because the generators in a pumped storage scheme can be synchronised within seconds, providing power quickly to meet peak demand or sudden demand for electricity [4]. There is much research, in Ireland, into pumped hydro storage in combination with wind energy and there are a further 5 pumped hydro generators in the planning process with a total capacity of 415MW [12].

\subsection{Hydrogen}

Converting wind energy to store as hydrogen is not a new concept. In 1891 Danish scientist Poul La Cour received support from the Danish government and an experimental windmill at Askov was built, where wind energy was used to create hydrogen \& electricity.

Hydrogen is a clean energy carrier that can be produced from any primary energy source. When burnt directly or used in a chemical reaction, it only produces water and heat $[13,14]$. The emergence and growth of the so called 'hydrogen economy' holds great promise of meeting simultaneously concerns over security of energy supply and climate change. As an energy carrier, hydrogen is to be compared to electricity. Hydrogen and electricity allow interoperability and flexibility in balancing centralised and decentralised power systems [15].

\subsection{Fuel Cells}

Fuel cells are electrochemical devices which offer a promising alternative to traditional power sources and provide the most effective device for converting hydrogen into electricity. Fuel cells produce electricity with a reaction of the fuel (hydrogen) and air. Fuel cells have the advantage of being clean, only producing water as a by product. The efficiency of a fuel cell varies depending on the type; SOFC with a combined heat and power (CHP) system for example, can have a system efficiency of up to $65 \%$.

\subsection{Polymer Electrolyte Membrane Fuel Cells}

Polymer Electrolyte Membrane (PEM) fuel cells, Figure 6, operate on the principle of an electrochemical reaction between hydrogen and oxygen with the aid of a catalyst (platinum). Hydrogen fuel is channelled through field flow plates to the anode on one side of the fuel cell while oxygen from the air is channelled to the cathode on the other side of the cell. At the anode a platinum catalyst causes the hydrogen to split into positive hydrogen ions (protons) and negatively charged electrons. At the cathode, the electrons and positively charged hydrogen ions combine with oxygen to form water. The PEM fuel cell can produce high current densities, have fast start up and shut down times and its operating temperature can be between $60^{\circ} \mathrm{C}$ and $80^{\circ} \mathrm{C}$, compared to other fuel cell types, such as the SOFC where the operating temperature is approximately $700^{\circ} \mathrm{C}[16]$.

\subsection{Internal Combustion Engines}


Internal combustion engines (ICEs) can also convert the produced hydrogen to electricity via a generator. Hydrogen has a high octane rating and higher specific heat ratio than gasoline, which leads to a more efficient engine. Some hydrogen engines have been tested to be $20 \%$ more efficient than gasoline ICEs [17]. Most alternative technologies have not been developed to the same degree as ICEs and there is potential to improve the efficiency of the ICEs further. ICEs offer a transition from a known proven technology to a more efficient fuel cell technology, which has been briefly described, a logical step towards placing hydrogen technologies in stationary applications.

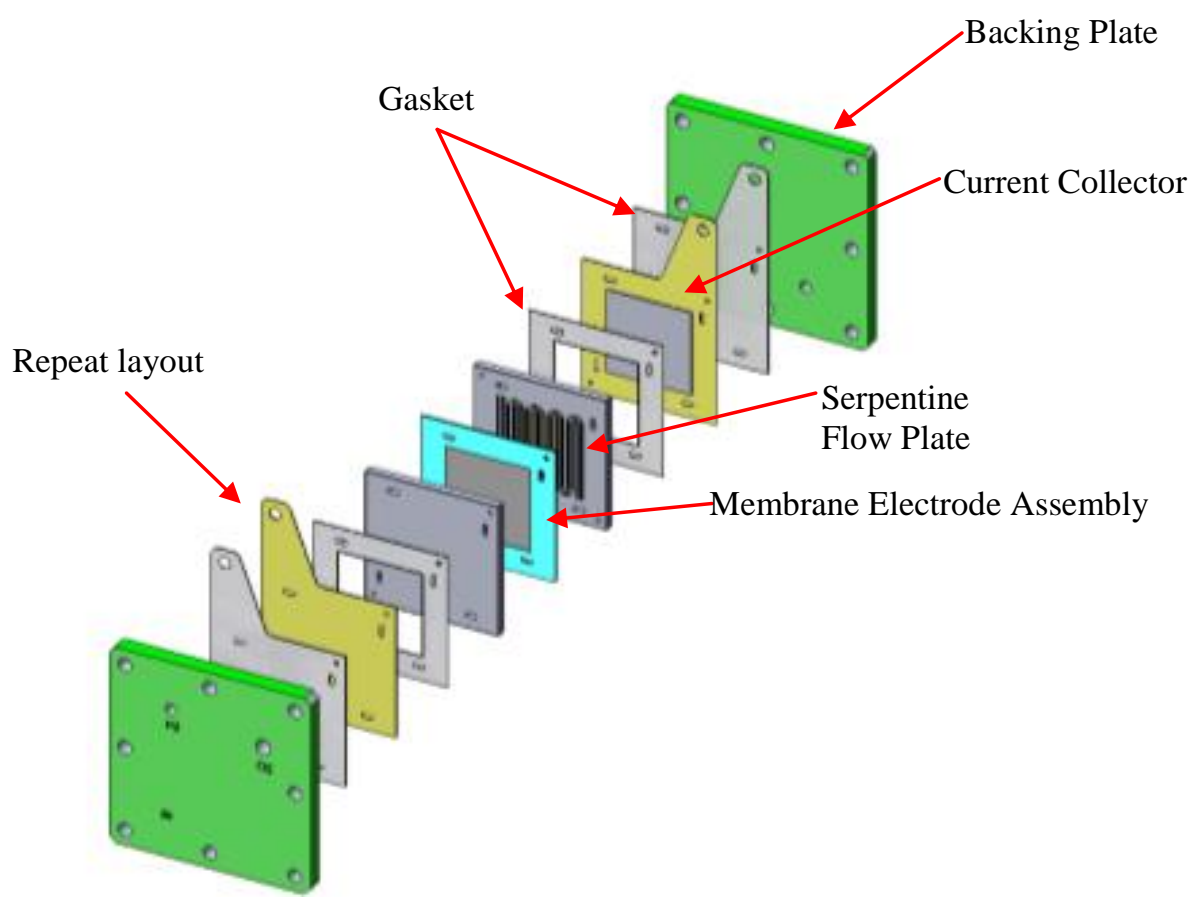

Figure 6 Exploded view of a proton exchange membrane (PEM) fuel cell.

\subsection{Wind / Hydrogen Hybrid System}

In a wind / hydrogen hybrid system the main aim is to use the excess electrical energy, which would otherwise be wasted, to decompose water in an electrolyser to produce and store that energy as hydrogen. The basics of a complete system would include the wind turbine, an electrolyser, hydrogen storage and a fuel cell, please refer to [18] for a review of the technology. The renewable energy source (e.g. wind turbine system) produces electricity as normal, delivering the idle supply of electricity to the customer (or grid). This value would be decided on at the design stage of the whole system. The excess electricity, controlled by the power control system, would be directed to the electrolyser unit which generates $\&$ stores hydrogen. When the wind turbine shuts off due to low or high wind speed the hydrogen can be channelled to a fuel cell generating the constant supply of electricity needed for a set duration; also decided on in the design stage. In addition when demand is low on the grid and the wind is favourable the wind turbine directs its energy again to the electrolyser unit generating more stored energy.

The wind / hydrogen hybrid system would have huge benefits to local and distributed power. The storage would be proportional to demand and the system would be always ready to use the storage capacity when needed. Balance of plant equipment is always part of the overall system. For example in order to efficiently produce hydrogen from wind power, it has been suggested that an electric double layer capacitor (EDLC) can be used as the electric 
power buffer medium for the system to ensure stabilization of the amount of the hydrogen generation and reduce the hydrogen load capacity [19]. In another study it has been noted that high pressure PEM electrolyte water electrolysis is especially conducive to distributed hydrogen generation options where the cost of transporting hydrogen can be prohibitive [20]. PEM fuel cells have short start up and shut down times unlike other fuel cell systems and could react very well to fluctuations on the grid. The wind farm would become part of the solution to fluctuating power issues instead of adding to them.

\subsection{Hydrogen Energy Storage}

When hydrogen is used to transmit renewable electricity, only $51 \%$ can reach the end user if produced by electrolysis due to efficiency losses and the need for compression. Conventional electric storage technologies allow between $75 \%$ and $85 \%$ of the original electricity to be delivered [21]. However, Schoenung [22, 23] compared energy storage technologies; batteries, compressed air (CAES), pumped hydro, superconducting magnetic (SMES) and super-capacitors with hydrogen electric generation and storage. The cost, effectiveness, quality, UPS, transmission, distribution, spinning, load management and load levelling abilities were examined. It was concluded that hydrogen compares well with other energy storage technologies in some niche applications:

- Hydrogen fuel cells can be used in power quality applications where 15 seconds or more of ride-through are required.

- Large hydrogen systems compete with CAES for cost-effective load management.

- Hydrogen fuel cells or combustion engines are suitable for distributed generation with dispatch.

- On a life-cycle cost basis for long duration applications, fuel cell technology competes with battery systems at discharge times greater than about 2 hours depending on cost assumptions, and with hydrogen-fuelled engines at discharge times greater than about 4 hours.

- High-efficiency reversible fuel cells make sense for long duration discharge (> $4 \mathrm{hrs}$ ).

Korpas et al [24] gave an overview of the opportunities that exist for combining wind power and hydrogen production in weak grids. Hydrogen storage can be applied in both isolated and grid-connected systems and utilized for stationary energy supply and/or as a fuel for transportation. The results also indicated that there are large benefits of using the grid as backup for hydrogen production in periods with low wind speed. Kassem's study [25] applied methods of risk analysis to evaluate the simultaneous effect of multiple input uncertainties of wind energy, and provide an assessment of the techno economic viability of offshore wind farms for electrolytic hydrogen production. It was concluded that the capacity factor of wind turbine has a dominant effect on the wind power economy. Electricity surplus, during low demand hours could be converted to hydrogen and stored [26, 27]. This hydrogen could be used later to feed fuel cells and compensate wind generator output during peak demand hours.

\section{SUMMARY OF ENERGY STUDIES IN DENMARK, HOLLAND \& NORWAY}

\subsection{Denmark}

Currently Denmark has $20 \%$ of its electricity demand powered by wind power and $50 \%$ from CHP. To date excess energy production is exported to neighbouring countries [28]. Lund et al $[29,30]$ assessed the value of integrating CAES into future sustainable energy systems in Denmark with high fluctuating renewable energy sources. It was concluded that in energy systems with very high shares in wind or CHP, CAES is not as feasible as other storage systems but could be used in combination with other storage systems. 
Studies by Lund [31] have investigated different energy systems and regulation strategies to integrate wind power. Some of these strategies included CHP from fuel cells and electric vehicles possibly powered by fuel cells and hydrogen. In another study by Mathiesen et al [32], hydrogen storage is incorporated into an energy system model to avoid excess electricity production by wind and reduce the consumption of fossil fuels, reducing $\mathrm{CO}_{2}$. However, in a closed system, this study concluded that hydrogen storage / electrolyser / fuel cell system and electrolysis CHP systems would reduce excess electricity but only marginally reduce fossil fuel consumption in the system. Heat pump and heat storage alternative was concluded to be better in reducing fuel consumption if used in conjunction with CHP.

\subsection{Holland}

Schenk et al [33] researched wind energy, electricity and hydrogen in the Netherlands. The research identified the potential energetic benefits of integrated hydrogen production in electricity systems with high wind energy penetration. However the research concluded that the use of system losses for hydrogen production via electrolysis is beneficial in situations with about $8 \mathrm{GW}$ or more wind energy capacity in the Netherlands. It was noted then the 2020 Dutch policy goal of $6 \mathrm{GW}$ will not benefit from hydrogen production in terms of systems efficiency.

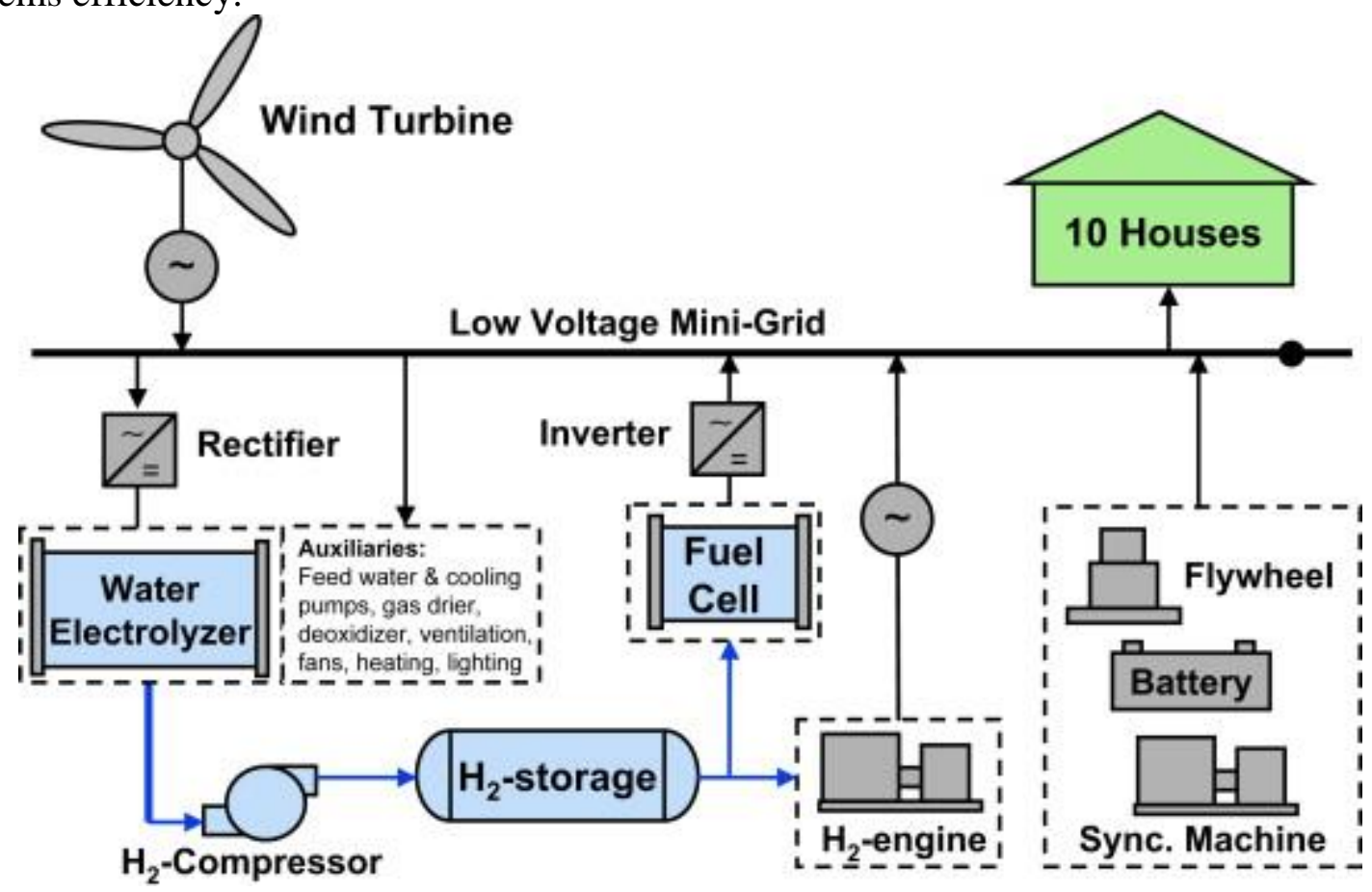

Figure 7 System schematic of the wind/hydrogen demonstration plant installed at Utsira [44].

\subsection{Norway}

Greiner et al [34] presented a method for assessment of wind-hydrogen energy systems. The method includes chronological simulations and economic calculations, enabling optimised component sizing and calculation of hydrogen cost. Simulated results concluded that a grid-connected system is by far the most economical at $2.8 € / \mathrm{kg}$ of hydrogen compared with $6.2 € / \mathrm{kg}$ of hydrogen for an isolated system.

In 2004 a demonstration project by a Norwegian company, Norsk Hydro (now Statoil Hydro), was launched on a small island, Utsira, $20 \mathrm{~km}$ off the Norwegian coast in the North Sea. The primary electricity supply for ten houses on the island is a $600 \mathrm{~kW}$ wind turbine, with energy storage in the form of compressed hydrogen and flywheels. High wind speeds on the island provide excess wind-generated power to an electrolyser $(10 \mathrm{Nm} 3 / \mathrm{h})$ and 
compressor, which supply hydrogen to storage cylinders (2400 Nm3, 200 Bar). A fuel cell $(10 \mathrm{~kW})$ and hydrogen powered ICE generator provide back-up power to the houses, and excess and off-peak electricity is used to generate hydrogen as a transport fuel on the island, see Figure 7. The success of this project continues and much information has been gathered from the project. Approximately $90 \%$ availability was achieved with good power quality and satisfied customers. In addition no accidents were reported during the course of the project and recommendations of the size of the storage tanks and the necessity of a remote access control system have been noted [35].

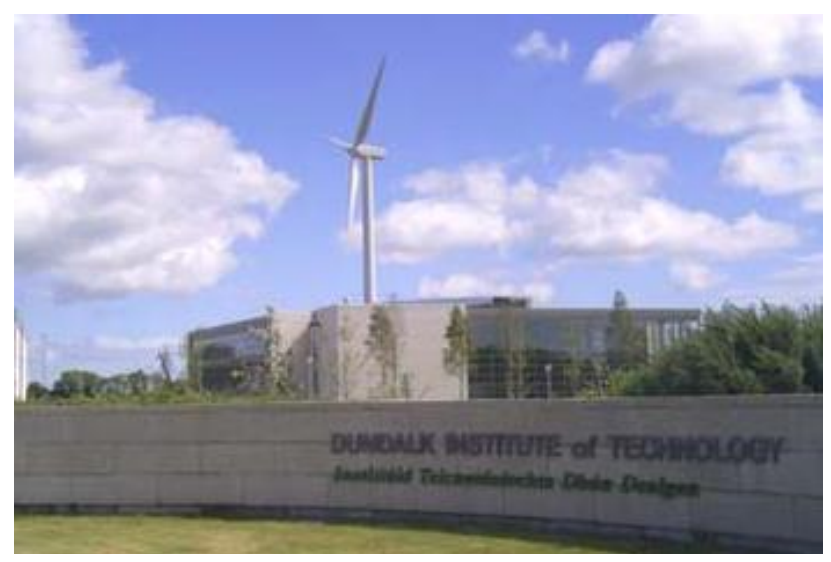

Figure 8 Wind turbine at the Dundalk institute of technology.

\section{ENERGY STUDIES IN IRELAND}

\subsection{Dundalk Town}

Dundalk town on the east coast of Ireland and its Institute of Technology (DKIT) took on a bold challenge in 2002 by starting to develop a strategy to meet EU 2020 target by 2010; and now they are well on the way to achieving that goal. The aim of the project was to examine, in a structured way, the interaction of all aspects of sustainable development and the potential of the region to act as a national model for sustainable energy. A wind turbine (without storage capability) was installed in 2005, Figure 8, and the average output power is 240 kilowatts about $28 \%$ of the rated power. The turbine that is installed is a Vestas V52 turbine. The tower is 60 metres high and each of the 3 blades is 25 metres long. The generator is rated at $850 \mathrm{~kW}$ maximum output, but exportation regulations limit the turbines output to $700 \mathrm{KW}$ (loss of $\sim 7 \%$ production, that could avoided if energy storage was available). In 2006, which was a low wind year, the turbine produced 1,430,320 kWh of electricity and was available $97.4 \%$ of the time, $30 \%$ of the electricity generated by the wind turbine was exported. DKIT's annual electricity need is approximately 3 million $\mathrm{kWh}$ and the wind turbine is able to supply $33 \%$ of DKIT's needs. The other $67 \%$ is imported from the grid with a bill of $€ 237,000$, but saving $€ 130,000$ in 2006 with an average electricity consumption of $350 \mathrm{kWh}$ every hour. The total cost of the wind turbine was $€ 1.127 \mathrm{~m}$ (including $13.5 \% \mathrm{VAT}$ ) but the turbine reduces the institute's carbon footprint by 1300 tonnes per annum and saves around $€ 125000$ a year on the institute's electricity; it should pay for itself in 7 years [36].

Figure 9 shows the power production of the DKIT and power import from the grid in relation to power demand over a sixty two day period from September 2009 to November 2009. It is clear that the average electricity demand in DKIT is not met all of the time. It also shows that electricity production can reach very high levels, exceeding $700 \mathrm{KW}$ on occasion and production is rarely stopped. The graph includes the electricity imported from the grid and how the grid compensates for the variability of the wind turbine. 


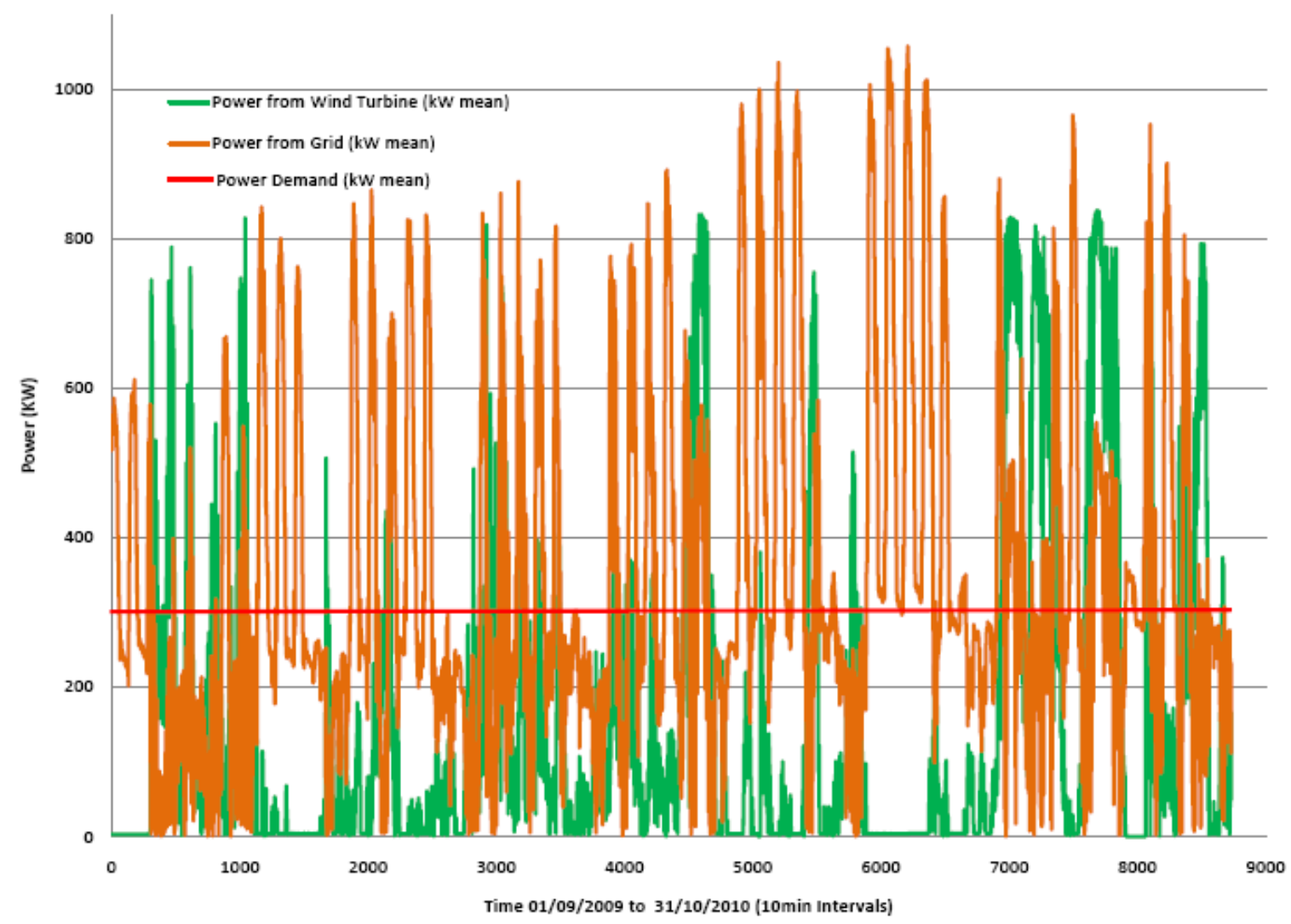

Figure 9 DKIT power consumption from wind turbine \& grid (information was courtesy of Lawrence Staudt of 'CREDIT').

\subsection{Hydrogen Systems}

González et al [37] studied the viability of hydrogen production via electrolysis using excess wind power within the context of the enormous wind energy resource in Ireland. The system, see Figure 10, consists of the wind generator, electrolyser, a fuel cell and a control system. The simulated results reveal that many factors would affect the economic viability of the technology:

- Significant cost reductions in electrolyser and associated balance of plant equipment is needed

- A low average surplus wind electricity cost

- High hydrogen market price.

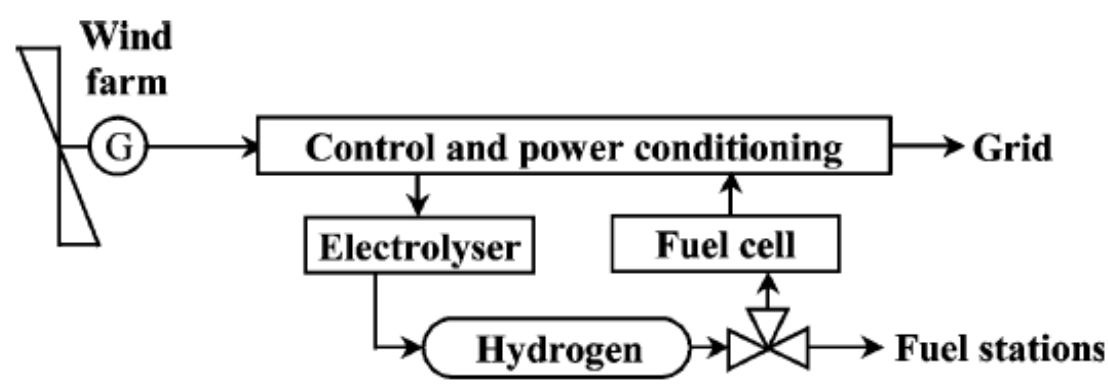

Figure 10 General layout of wind hydrogen system [37]. 
A study of electricity storage technologies and their potential to address wind energy intermittency in Ireland was conducted in 2004 for Sustainable Energy Ireland [11]. Another study in 2005 looked at hydrogen production from off-peak wind to be used to power a bus transportation system. A rural and city bus application was proposed. It was concluded that the cost of the fuel cells for the buses was critical for the viability of the project [38].

Connolly et al [39] investigated using a deterministic input/output model, the steps towards a $100 \%$ renewable energy system for Ireland. The study looked at four 100\% renewable energy scenarios; biomass, hydrogen, electricity and a combination of all three. For each scenario different assumptions were made, including energy demand to be maintained at 2007 levels, solar thermal increased its share in the market and tidal and wave energy were introduced. The results showed that all scenarios had a lower primary energy supply, mostly due to more efficient systems and the use of CHP and district heating which, in the present system, is not common. It was also noted that he biomass system would not utilise wind energy as effectively as the electricity or hydrogen systems, due to the storage ability of these systems compared to the current fossil fuel or proposed biomass energy system. It was concluded that a combination of biomass, hydrogen and electricity proved the best with a $20 \%$ reduction in primary energy compared to 2007 levels and using a mix of hydrogen, electricity and biomass for transport.

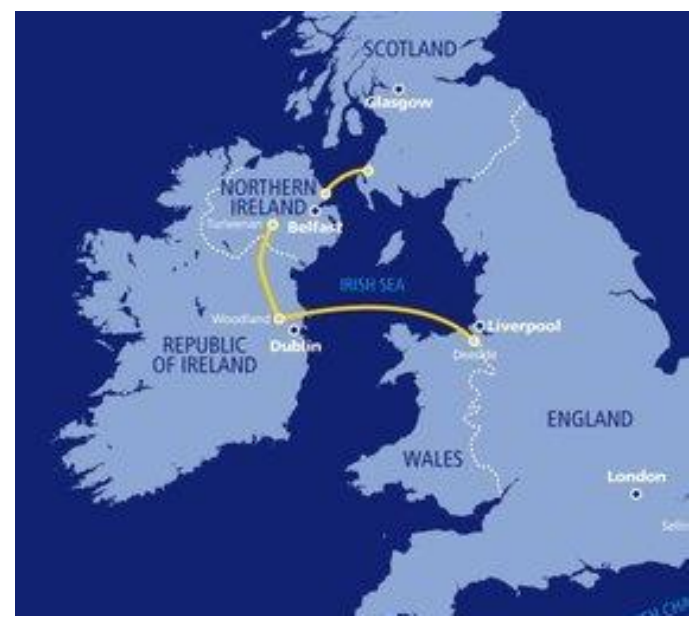

Figure 11 Electricity interconnects between Ireland \& Britain [40].

\section{DISCUSSION}

\subsection{Infrastructure Issues}

The Irish transmission system operator has much work to secure sustainable energy for Ireland. As electricity demand increases the transmission system has become strained and is still in urgent need for upgrades. Interconnecting with Britain has to date being a favoured, simple but very expensive, method to import and export energy from the Irish grid to the larger European market through Britain, reducing the intermittency of wind power. The Moyle interconnector, which has been operational since 2002, is an electricity transition line connected from Britain to Northern Ireland and has a capacity of $450 \mathrm{MW}$ export and $80 \mathrm{MW}$ import. Currently an East-West interconnector to connect north Dublin to Britain is under construction and has a capacity of $500 \mathrm{MW}$ at a cost of over $€ 600$ million, see Figure 11. Another interconnect, between Northern Ireland and the Republic of Ireland is in its planning stages. This will have a capacity of $350 \mathrm{MW}$ and cost $€ 200$ million. In addition two further interconnects between Ireland and Britain are planned, each with a capacity of 350MW [40]. 
Diversity of wind farm sites has also been confirmed to be effective in reducing the intermittency of wind powered generation on the grid, but the addition of wind farms scattered around the country in locations where there is much wind and little cable infrastructure has given rise to transmission problems. As can be seen in Figure 12 more than $21 \%$ of the final consumption of energy in Ireland is wasted due transmission losses. Ireland does not have what would internationally be recognised as a backbone very high voltage grid of an industrialised country such as the Britain or France. However, with the aid of storage technologies and new strategies in distributed power, these issues may not contribute to excessive loss as they currently do with the present centralised system.

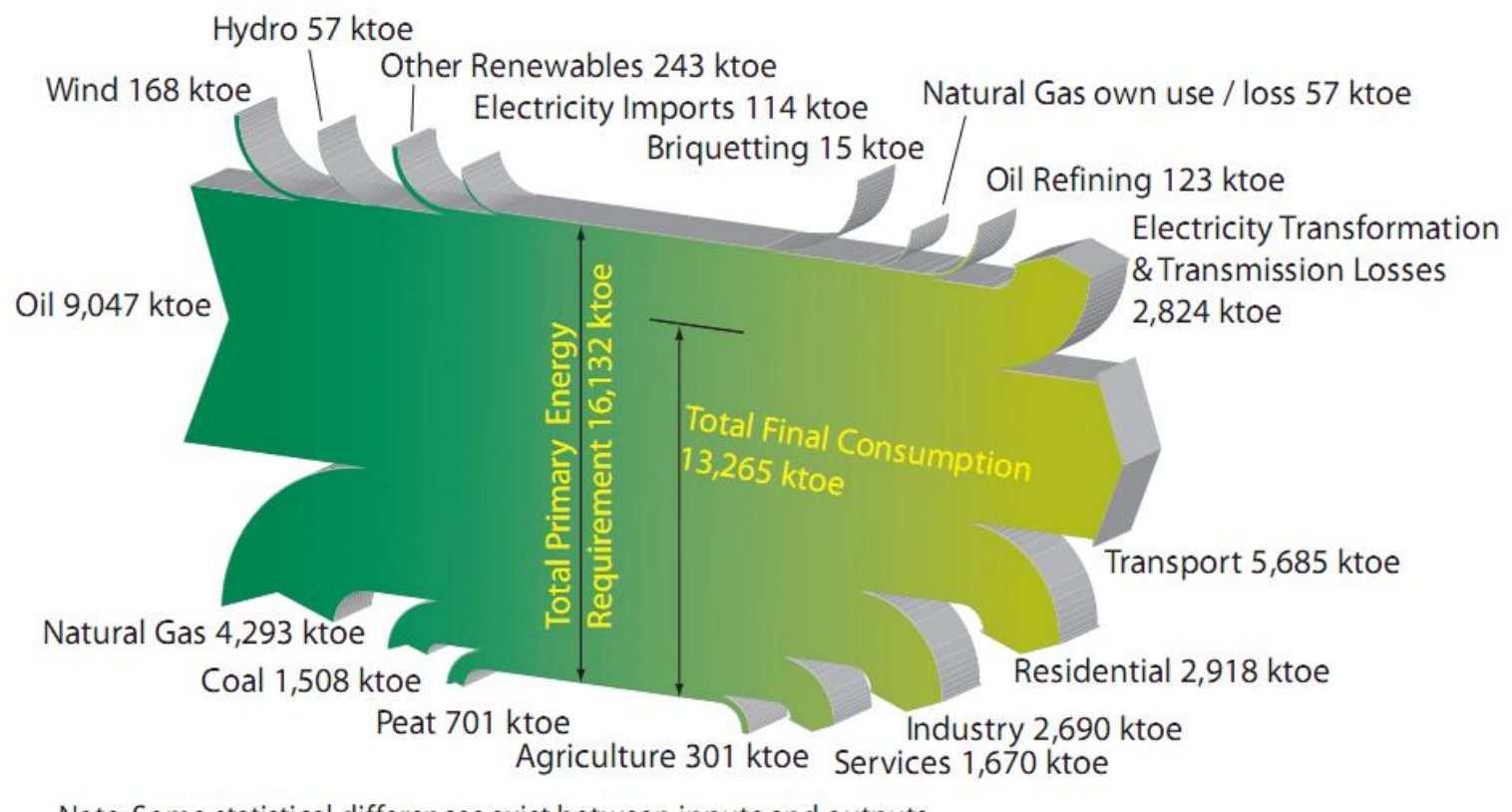

Note: Some statistical differences exist between inputs and outputs

Figure 12 Energy Flow Ireland 2007[45].

\subsection{Irish Possibilities (Dundalk Example)}

From the results in Figure 9 a few issues are clearly visible:

- Because of exportation regulations $150 \mathrm{KW}$ of power is lost on occasion.

- In an average year at least $30 \%$ of the electricity is exported to the grid at a low feed in tariff rate

- It is noticed that when the grid tries to balance the load for DKIT large fluctuations of input power is noticed, some of this fluctuation power can be wasted

If DKIT added a system similar to the Norwegian Utsira example, a more flexible, effective and efficient energy system could be created. The design and configuration of a renewable energy generating system (e.g. wind turbine system), depends on a huge range of criteria; the energy capacity of the system; the cost of the system; the availability of different forms of storage capacity; pumped hydro etc; the accessibility of the site and safety to just name a few. The main objectives of the system are to produce the necessary power, reduce waste and increase efficiency. DKIT are half way there and the island of Ireland could follow.

As noted in the literature, a possible economic and effective way to ensure waste is reduced is to store the otherwise wasted energy in a form that is readily available for power generation, in a cost effective way. Hydrogen by electrolysis from renewable energy has great potential to complement and extend the cost competitive position and viability against conventional fuel sources. New regulations may compel wind farms to operate normally with 
idle generation capacity to allow for the variability of the wind and to promote the use of the excess wind power to produce hydrogen [41].

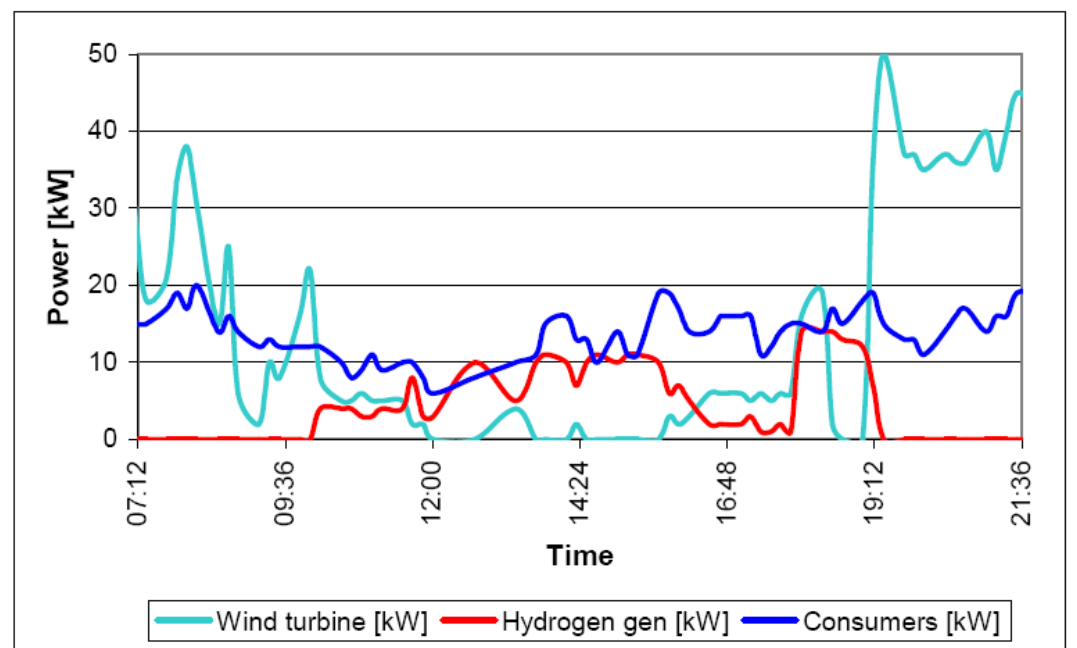

Figure 13 During a period of low wind hydrogen is used to produce electricity and balance customer demand [35].

Figure $13 \& 14$ show operational data from the Norwegian Utsira wind / hydrogen project. The customer need is matched with generating capacity, Figure 13. When the wind increases the electrolyser generates hydrogen, Figure 14. As wind decreases the fuel cell or ICE generates electricity from the stored hydrogen. It is noted in literature that more large scale demonstration projects like Utsira, and the dissemination of key lessons learned from them, is important in order to;

- Prove the technology

- Improve public awareness and acceptance

- Improve cost competitiveness

- Reduce market barriers.

A project similar to the Norwegian Utsira wind / hydrogen project could be piloted in Ireland and a site similar to Dundalk Institute of Technology could be used to demonstrate and test the system.

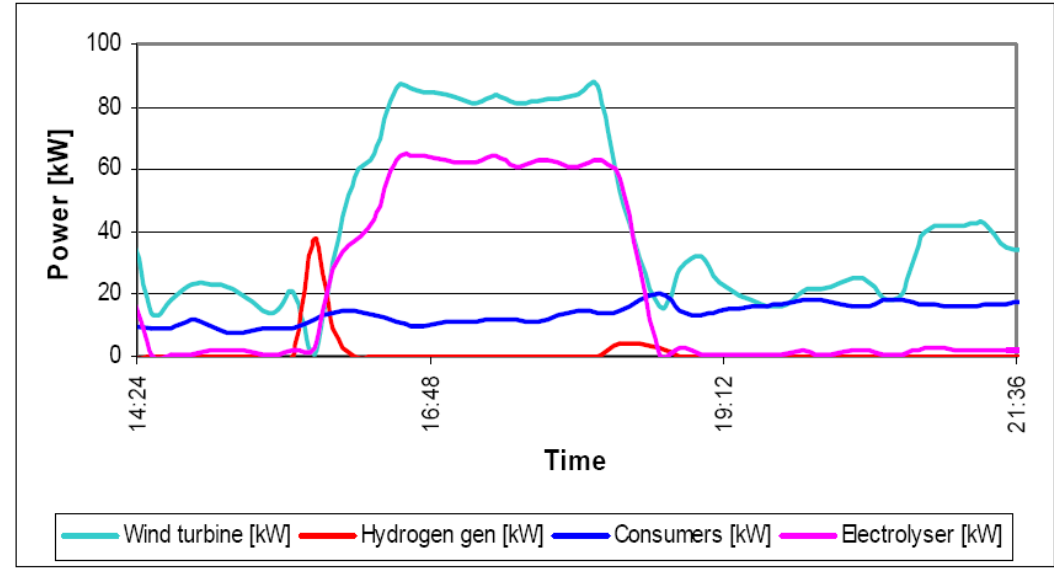

Figure 14 During a period of high wind hydrogen is produced and during low wind hydrogen is used to

\section{CONCLUSION}

balance customer demand $[35]$.

Clean secure sustainable energy is what is needed by every country. A survey conducted in 2006 [42] reported that Europeans appear to see renewable energy (wind and solar energy being the most popular choice) as a solution for future energy needs in thirty years. 
Electricity production from wind energy depends on weather conditions. The problem of intermittency can be solved by providing energy storage capability reducing the need for wasteful backup power reserves. Hydrogen storage and efficient fuel cell utilisation is a possible answer to some of the current energy storage and delivery issues. Hydrogen and electricity together represent one of the most promising ways to realise sustainable energy, and fuel cells provide the most effective device for converting hydrogen into electricity.

Going forward to achieve high levels of renewable energy generation, similar distributed wind / hydrogen hybrid systems could reduce the need for curtailment of wind farms, save wasted energy, reduce backup power, reduce transmission losses, generate large revenue by selling power at peak times, ensure security of supply and reduce the need for costly interconnects to Europe.

Although the potential benefits of hydrogen and fuel cells are significant, many challenges, technical and otherwise, must be overcome before they will be able to offer consumers a competitive alternative. There are societal issues related to the introduction of a new energy carrier into everyday use, including public acceptance. Hydrogen, in common with other alternative fuels, introduces different safety and regulatory issues which need to be understood and tackled by appropriate authorities.

The challenge is given to a pioneering person or company to lead the way forward to build just one single pilot project, in Ireland, using only one wind turbine if necessary to produce a wind / hydrogen hybrid system to produce electricity, storing the excess as hydrogen and using it when necessary in a fuel cell system delivering sustainable constant energy to the customer.

\section{RFERENCES}

[1]Phillips L. EU unveils comprehensive climate and energy package. 2009. See Also: http://euobserver.com/877/25513.

[2]Department of Energy Ireland. Carbon Budget 2008. Ireland,2010. See Also: http://www.environ.ie/en/Environment/News/MainBody,18676,en.htm.

[3]Department of Energy Ireland. National Renewable Energy Action Plan IRELAND. Ireland,2010. See Also: http://www.dcenr.gov.ie/Energy/.

[4]ESB. Irish Generating Stations. 2008. See Also: http://www.esb.ie/main/aboutesb/powerstations/poolbeg/home/index.jsp.

[5]Klimstra J. A hybrid solution [power generation from renewables]. Engineering and Technology 2008;3(4):52-54.

[6]Bömer J, Burges K, Nabe C, Pöller M. All Island TSO Facilitation of Renewables Studies (prepared for $\begin{array}{llll}\text { EirGrid } & \text { Ireland,2010. } & \text { See } & \text { Also: }\end{array}$ http://www.eirgrid.com/media/Faciltiation\%20of\%20Renwables\%20WP3\%20Final\%20Report.pdf.

[7]Hall PJ, Bain EJ. Energy-storage technologies and electricity generation. Energy Policy 2008 12;36(12):4352-4355.

[8]Baker J. New technology and possible advances in energy storage. Energy Policy 2008 12;36(12):4368-4373.

[9]Hadjipaschalis I, Poullikkas A, Efthimiou V. Overview of current and future energy storage technologies for electric power applications. Renewable and Sustainable Energy Reviews 2009 9;13(6-7):1513-1522. 
[10]Dell RM, Rand DAJ. Energy storage - a key technology for global energy sustainability. J.Power Sources 2001 11/30;100(1-2):2-17.

[11]Gonzalez A, Ó Gallachóir B, McKeogh E. Study of Electricity Storage Technologies and Their Potential to Address Wind Energy Intermittency in Ireland. Sustainable Energy Authority of Ireland,2010. See Also: http://www.seai.ie/uploadedfiles/FundedProgrammes/REHC03001FinalReport.pdf.

[12]Dennehy E, Howley M, Ó Gallachóir B, Barriscale A. Renewable Energy in Ireland 2010 Update. The Sustainable Energy Authority of Ireland,2010. See Also: http://www.seai.ie/Publications/Statistics_Publications/SEI_Renewable_Energy_2010_Update/RE_in_Ire_2010 update.pdf.

[13]O'Hayre R, Cha S, Colella W, Prinz FB. Fuel Cell Fundamentals. USA: John Wiley and Sons; 2006.

[14]Peavey MA. Fuel From Water: Energy Independence with Hydrogen. 11th ed. Louisville KY: Merit Inc; 2003.

[15]European Commission. Introduction to Hydrogen as an Energy Carrier. 2009. See Also: http://ec.europa.eu/research/energy/pdf/hydrogen_22002_en.pdf.

[16]Supramaniam S. Fuel Cells: From Fundamentals to Applications New York: Springer Science \& business Media; 2006.

[17]S\&T Consultants. Hydrogen Pathways Greenhouse Gas Emissions \& Energy Use (Prepared for Fuel Cells Canada). Canada,2009. See Also: annex18.sharepointsite.net/Public/National\%20Documents/Canada/GreenHouseGas-Energy-Use.pdf.

[18]Sherif SA, Barbir F, Veziroglu TN. Wind energy and the hydrogen economy-review of the technology. Solar Energy 2005 5;78(5):647-660.

[19]H. Kaneuchi, T. Yachi and T. Tani. Effect of an EDLC in a wind turbine system for hydrogen production. Anonymous International Telecommunications Energy Conference Piscataway, NJ, USA: IEEE; 30 Sept.-4 Oct. 2007; 557-62.

[20]Larry Moulthrop, Jesse Hayes and Mike Spaner. P.E.M. Water electrolyzers in renewable energy capture to hydrogen. Anonymous 2007 AIChE Spring National Meeting, April 22, 2007 - April 27 Houston, TX, United states: American Institute of Chemical Engineers; 2007; .

[21]Hammerschlag R, Mazza P. Questioning hydrogen. Energy Policy 2005 11;33(16):2039-43.

[22]Schoenung S. Hydrogen energy storage comparison. 2009. See Also: http://www.osti.gov/bridge/purl.cover.jsp;jsessionid=E9D00F36F29955E2C25784F6475D8F35?purl=/763084JtAYM6/webviewable/.

[23]Schoenung SM. The long and short of it [energy storage]. Modern Power Systems 2001 05;21(5):25-30.

[24]Korpas M, Greiner CJ. Opportunities for hydrogen production in connection with wind power in weak grids. Renewable Energy 2008;33(6):1199-1208.

[25]Nabil Kassem. Offshore wind farms for hydrogen production subject to uncertainties. Anonymous 2003 International Joint Power Generation Conference, June 16, 2003 - June 19 Atlanta, GA, United states: American Society of Mechanical Engineers; 2003; 857-864.

[26]Sigfusson TI. Pathways to hydrogen as an energy carrier. Philosophical Transactions of the Royal Society London, Series A (Mathematical, Physical and Engineering Sciences) 2007 04/15;365(1853):1025-42. 
[27]F. Ibanez, A. Perez-Navarro, C. Sanchez, I. Segura, E. Bernal and J. Paya. Wind generation stabilization using a hydrogen buffer. Anonymous 2007 European Conference on Power Electronics and Applications, EPE, September 2, 2007 - September 5 Aalborg, Denmark: Inst. of Elec. and Elec. Eng. Computer Society; 2007; .

[28]Salgi G, Lund H. System behaviour of compressed-air energy-storage in Denmark with a high penetration of renewable energy sources. Appl.Energy 2008;85(4):182-189.

[29]Lund H, Salgi G. The role of compressed air energy storage (CAES) in future sustainable energy systems. Energy Conversion and Management 2009 05;50(5):1172-9.

[30]Lund H, Salgi G, Elmegaard B, Andersen AN. Optimal operation strategies of compressed air energy storage (CAES) on electricity spot markets with fluctuating prices. Appl.Therm.Eng. 2009;29(5-6):799-806.

[31]Lund H. Large-scale integration of wind power into different energy systems. Energy 2005;30(13):24022412.

[32]Brian Vad Mathiesen and Henrik Lund. Fuel-efficiency of hydrogen and heat storage technologies for integration of fluctuating renewable energy sources. Anonymous 2005 IEEE Russia Power Tech, PowerTech, June 27, 2005 - June 30 St. Petersburg, Russia: Inst. of Elec. and Elec. Eng. Computer Society; 2005;

[33]Schenk NJ, Moll HC, Potting J, Benders RMJ. Wind energy, electricity, and hydrogen in the Netherlands. Energy 2007 10;32(10):1960-71.

[34]Greiner CJ, KorpAs M, Holen AT. A Norwegian case study on the production of hydrogen from wind power. Int J Hydrogen Energy 2007 07;32(10-11):1500-7.

[35]Nakken T, Strand LR, Frantzen E, Rohden R, Eide PO. The Utsira wind-hydrogen system - Operational Norway,2010. See
http://www.ewec2006proceedings.info/allfiles2/135_Ewec2006fullpaper.pdf.

[36]MacArtain P. Dundalk Sustainable Energy Zone- A Campus in the Community. 2008. See Also: http://www.international-sustainable-campus-network.org/fileadmin/downloads/Panel_A1_Paul_McArtain.pdf.

[37]Gonzalez A, McKeogh E, Gallachoir BO. The role of hydrogen in high wind energy penetration electricity systems: the Irish case. Renewable Energy 2004 04;29(4):471-89.

[38]Sustainable Energy Ireland. Emerging Energy Technologies in Ireland: A Focus on Carbon Capture and $\begin{array}{lllll}\text { Hydrogen. } & \text { Sustainable } & \text { Energy } & \text { Ireland,2010. } & \text { See }\end{array}$ http://www.seai.ie/Publications/Emerging_Technologies/CO2_Hydrogen_Capture_fnl.pdf.

[39]Connolly D, Lund H, Mathiesen BV, Leahy M. The first step towards a 100\% renewable energy-system for Ireland. Appl.Energy ;In Press, Corrected Proof.

[40]Office of Gas \& Electricity Markets. Electricity Interconnector Policy 2010. UK,2010. See Also: http://www.ofgem.gov.uk/Europe/Documents1/Interconnector\%20policy\%20consultation.pdf.

[41]Mantz RJ, De Battista H. Hydrogen production from idle generation capacity of wind turbines. Int J Hydrogen Energy 2008;33(16):4291-4300.

[42]European Commission. Energy Technologies: Knowledge - Perception - Measures. 2009. See Also: http://www.eurosfaire.prd.fr/7pc/doc/1188398813 energy tech_eurobarometer_en.pdf.

[43]De Vries E. Optimism in Offshore Wind market buzzing with activity. 2009. See Also: http://www.renewableenergyworld.com/rea/news/article/2009/12/optimism-in-offshore-wind-a-market-buzzingwith-activity. 
[44]Ulleberg Ø, Nakken T, Eté A. The wind/hydrogen demonstration system at Utsira in Norway: Evaluation of system performance using operational data and updated hydrogen energy system modeling tools. Int $\mathbf{J}$ Hydrogen Energy 2010 3;35(5):1841-1852.

[45]Howley M, Ó Gallachóir B, Dennehy E. Energy in Ireland 1990 - 2007. Ireland,2010. See Also: http://www.seai.ie/Publications/Statistics_Publications/Energy_in_Ireland/Energy_in_Ireland_1990-2007.pdf. 